\title{
IAMJ
}

INTERNATIONAL

AYURVEDIC

MEDICAL JOURNAL

ISSN: 2320-5091

Impact Factor: 6.719

Case Report

\section{A CASE REPORT OF AYURVEDIC MANAGEMENT OF SHITTAPITTA (URTICARIA)}

\section{Lekha Soni ${ }^{1}$, Pramod Kumar Mishra ${ }^{2}$, Indu Sharma ${ }^{3}$, Garima Yadav ${ }^{4}$}

${ }^{1}$ MD Scholar P.G. Department of Kayachikitsa,

${ }^{2}$ Professor and HOD, P.G. Department of Kayachikitsa, University College of Ayurveda,

Dr. Sarvepalli Radhakrishnan Rajasthan Ayurved University Jodhpur, Rajasthan, India.

${ }^{3}$ Associate Professor P.G. Department of Kayachikitsa, Govt. Ayurvedic College of Udaipur, Rajasthan, India

${ }^{4}$ MD Scholar P.G. Department of Kayachikitsa,

Corresponding Author: $\underline{\text { drlekhasoni@gmail.com }}$

https://doi.org/10.46607/iamj5109102021

(Published Online: October 2021)

Open Access

(C) International Ayurvedic Medical Journal, India 2021

Article Received: 17/09//2021 - Peer Reviewed: 05/10/2021 - Accepted for Publication: 06/10/2021

Check for updates

\begin{abstract}
In Urticaria Vata and Kapha are two doshas that are primarily vitiated and being mixed with pitta (Pittena Saha Sambhooya) spreads internally and Externally (Bahir Aantah Visarpah) and results in to 'Shittapitta-Udarda-Kotha' ${ }^{\text {. }}$ Due to Pitta dosha they create redness, swelling on the skin and moderate to severe itching on the skin. Ayurveda Herbo minerals preparation cures urticaria by balancing Tridoshas in the body. Shittapitta manifests due to exposure to various poisonous materials (allergens), cold environment and intake of Asatmya Ahar Vihar. In modern science, it is compared with urticaria. Hives (urticaria) are red, itchy welts that occur when the skin meets allergen releases histamine and other chemicals. The welts vary in size, appear and then disappear repeatedly as the reaction runs its course. The condition is considered chronic hives if the welts appear for more than six weeks and recur frequently over months or years. Episodes of urticaria may relapse for days, weeks, months or years. In Ayurveda Herbo-minerals preparation effectively treat Shittapitta and restore healthy skin by balancing Tridosha and Sapta dhatu in the body.
\end{abstract}

Keywords Urticaria, Shittapitta, Dosha, Tridosha, hives 


\section{INTRODUCTION}

In Brihata Trayi Symptoms of allergic skin, the reaction is mentioned as Kotha. Lately, Madhavakar mentioned it as a separate disease under the title Shittapitta-Udarda-Kotha ${ }^{2}$.

Madhavakar mentioned Shittapitta and Udarda as synonyms. He describes Shittapitta having Vatic dominancy and Udarda having Kaphaja dominancy. ${ }^{3}$

Charak has not directly used the word Shittapitta but the words Kotha, Utkotha and Udarda mentioned in the text.

The word "allergy" comes from the ancient Greek word allos meaning "other" and ergon meaning "work". Allergy is one of four forms of hypersensitivity and is formally called type I (or immediate) hypersensitivity. Allergic reactions occur due to excessive activation of certain white blood cells called mast cells and basophils by a type of antibody called Immunoglobulin E ( $\operatorname{IgE}$ ). This results in an inflammatory response that can range from mild discomfort to grave consequences. Skin allergies frequently cause rashes, or swelling and inflammation within the skin, which is known as a "wheal and flare" reaction characteristic of hives [Urticaria] and angioedema. "Urticaria is a recurrent, transient, cutaneous swelling with erythema which resolves within 24 hours without leaving any residual cutaneous signs. "A case with classical symptoms of Shittapitta was visited in Kayachikitsa OPD of Dr S.R. R.A.U Jodhpur. The patient was successfully treated with ayurvedic treatment. Follow up done every 7 days and she had no episode of rashes and itching. Results were found very encouraging.

\section{Aim and Objective}

To study the effect of Ayurvedic treatment (Shamana) in Shittapitta.

\section{Case Report}

\section{General information of the patient}

Kamala Jagid female patient aged 72 years came to the OPD OF Kayachikitsa Department of Dr S.R.R.A.U Jodhpur.

\section{Chief Complaint}

Irregular and raised erythematic rashes with severe itching on the whole body for 2 days. Rashes appear only for some time and then disappear after a certain time. Itching persists for a whole day.

Patient unable to sleep due to itching and Irritation.

\section{History of present illness}

The patient was well two days back, but suddenly small, irregular and raised red rashes appear all over the body with severe itching. Rashes disappear after taking antihistamine drugs (Cetirizine 10mg BD), but the episodes of itching and rashes reoccur very frequently.

The patient took allopathic treatment 2 days back, but no significant relief was seen so she came to Dr Sarvapalli Radhakrishnan Rajasthan Ayurveda University Jodhpur for further treatment.

\section{History of past illness and treatment taken}

No major history of any past systemic illness.

\section{Family History}

Not any relevant evidence

Examination

General Examination

- Pulse- 80 beats/min

- BP- $120 / 90 \mathrm{~mm}$ of $\mathrm{Hg}$

- Weight- $60.5 \mathrm{~kg}$

Ashtavidha Prakisha

- Nadi-Pittaj Kaphaj

- Mala-Vibandh

- Mutra- Samanya Matra, Shukla Varna, Sahaj Pravritti

- Jivha-Shweta varna, Sama Malaavritta

- Shabda-Spasta

- Sparsha-Anushnoshita but Ushna at the site of rashes

- Drik- Rakta varna, Kanduyukta Prakriti

- Aakriti-Madhyam

Dashwidha Prakisha

- Prakriti-Sharirik-Pittak-kaphaj Mansika-Rajasika

- Vikrati- Prakriti samasamvaya

- Saara-Rakta

- Samhanana-Madhyama

- Pramaanana-Madhyam

- Satmya-Sawarasa

- Satva-Madhyam 
- Ahara shakti-Abhyav Aharana shakti-Madhyam, Jaran shakti-Madyama

\section{Local examination}

- Irregular, raised, reddish rashes on the body especially on hand, leg and back.
- $\quad$ Shotha (Remarkable Swelling on the skin)

- Temperature elevated at the site of the rashes Diagnosis

Patient present complaints resemble the symptoms of Shittapitta as mentioned in the classical text.

\section{Treatment}

\section{Shaman Chikitsa}

\begin{tabular}{|c|c|c|c|c|c|}
\hline S. No & Treatment & & Dose of the food & Kala & Frequency and Anupana \\
\hline & $\begin{array}{l}\text { Cow ghee }(1 \mathrm{tbsp})+K \\
\text { Black pepper powder }(\mathrm{K}\end{array}$ & $\begin{array}{l}\imath d(1 \text { tbsp })+5 \\
\text { mirchi })\end{array}$ & & $\begin{array}{l}\text { An empty stomach in } \\
\text { the morning }\end{array}$ & Once a day \\
\hline & $\begin{array}{l}\text { Haridra khand } \\
\text { Gandhaka rasayana } \\
\text { Giloya satva } \\
\text { Sheet pitta bhanjana ra } \\
\text { Kamdudha rasa }\end{array}$ & $\begin{array}{l}-3 \mathrm{gm} \\
-500 \mathrm{mg} \\
-500 \mathrm{mg} \\
-250 \mathrm{mg} \\
-250 \mathrm{mg}\end{array}$ & 1tbsp (4-5gm) & After food & $\begin{array}{l}\text { Twice a day with Luke- } \\
\text { warm water }\end{array}$ \\
\hline & Tab. Urtiplex & & 2 Tablets & After Food & $\begin{array}{l}\text { Twice a day with Luke- } \\
\text { warm water }\end{array}$ \\
\hline & Mustard oil & & Local application & $\begin{array}{l}3 \text { times a day } \\
\text { On the site }\end{array}$ & - \\
\hline
\end{tabular}

\section{Composition of prescribed composition}

\begin{tabular}{|l|l|}
\hline Medicines & Content \\
\hline Haridra Khand & Haridra, Nishoth, Haritaki, Daruhaldi-, Nagarmotha, Ajwain, Ajamoda, Chitrakmool \\
\hline Sheet pitta Bhanjana rasa & $\begin{array}{l}\text { Shuddha Gandhak, Sharkara, Bhavana - Godugdha, Kwath of Dalchini, Ela, Tamalpatra, } \\
\text { Nagkeshar, Guduchi, Haritaki, Bibhitak, Amalaki, Shunthi, Ardrak Swarasa, And Bhrungaraj } \\
\text { Swarasa }\end{array}$ \\
\hline Kamdudha rasa & $\begin{array}{l}\text { Parada, Gandhaka, Tamra Bhasma, Kasish bhasma } \\
\text { rika and Amrta satva Kamdudha Ras }\end{array}$ \\
\hline Tablet Urtiplex & Manjishtha, Haridra, Khadir, Katuki, Daruharidra and Sariva \\
\hline
\end{tabular}

\section{Follow up and outcome}

\begin{tabular}{|l|l|}
\hline Date & Detail \\
\hline $09 / 01 / 21$ & $\begin{array}{l}\text { First visit to OPD } \\
\text { 1. Marich }+ \text { khand }+ \text { Cow ghee } \\
\text { 2. Giloy satva }+ \text { Gandhak rasayana }+ \text { Kamdudha rasa }+ \text { Shitpitta } \\
\text { bhanjana rasa }\end{array}$ \\
\begin{tabular}{|l|} 
3. Tb. Urtiplex \\
4. Local application of Mustard oil
\end{tabular} \\
$\begin{array}{l}\text { Second Visit in OPD } \\
\text { Mild relief in itching and Rashes } \\
\text { Frequency of the appearance of rashes decreases. } \\
\text { The same treatment continues. }\end{array}$ \\
\hline $25 / 01 / 21$ & $\begin{array}{l}\text { Third Visit in OPD } \\
\text { Rashes completely disappear. } \\
\text { Episodes of appearing rashes become negligible. } \\
\text { Completely relief from itching and burning sensation }\end{array}$ \\
\hline
\end{tabular}




\section{Result-}

Follow up of the patients was in every 7 days. Complete symptomatic relief after taking Medicines.

In the first week of treatment tendency of itching decreased a little bit, frequency of eruption of red patches also decreases.

In the second follow up, the patient has no complaint of itching and the frequency of the eruption of rashes was negligible.

The patient was completely relieved from all the symptoms of Shittapitta which are mentioned in the classical text.

\section{DISCUSSION}

Shittapitta is among the Twak vikara and have hetu just like Kotha and Udarda.Due to "Sheeta Marutadi Nidana'. Vata and kapha are the two doshas that are vitiated and being mixed with pitta spread internally and externally results in 'Shittapitta-Udarda-Kotha'.

Shittapitta has a significant impact in day-to-day life due to severe itching, rashes and recurrent appearance. Haridrakhand is a very effective medicine for any type of allergy and itchy skin

It's Katu-Tikta Rasa and Ushna-Tikshna-Laghu Guna helped to normalize vitiated Kapha and helped to remove the Strotavarodha. Kamdudha rasa, Sheettapittabhanjan rasa pacify aggravated Pitta. Maricha has its active principle called piperine, it has an anti-inflammatory activity that decreases rashes on the body. Gandhaka Rasayana is

used to treat several skin ailments such as Shitapitta, Kitibha, Dadru, Vicharchika etc.

Local application of Mustard oil gives relieves itching.

\section{CONCLUSION}

There is no specific and satisfactory treatment in Modern Science for the condition of Urticaria. But it can be effectively managed through the Ayurveda system of medicine. In Ayurveda, there are many formulations that have a lot of potential in the treatment aspect of allergy.

Nidan parivarjanam, breaking of the Samprapti and balancing Tridosha can cure urticaria. Combination of Gandhak Rasayan, Kamdudha rasa, Shittapitta bhanjana rasa, Giloya satva and Haridra khand with Urtiplex tablet and the local application of Mustard oil disintegrated the Samprapti (Pathogenesis) of Shittapitta with no adverse effect.

\section{REFERENCES}

1. Madhava Nidana - Hindi Translation by Narendranath Shastri, Motilal banarasidas Pratisthana, Delhi, Chapter 57, verse 1, pp. 638.

2. Madhava Nidana - Hindi Translation by Narendranath Shastri, Motilal Banarasidas Pratisthana, Delhi, Chapter 57, pp. 638

3. Yadunandana upadhyaya ed, Madhavanidanam with Madhukosha - vyakhyaya - vibusitam - II part, 50/14, 31st edition 2002, Choukhambha Sanskrit bhawan Varanasi, PP-168-169.

\section{Source of Support: Nil \\ Conflict of Interest: None Declared}

How to cite this URL: Lekfa Soni et al: $\mathcal{A}$ Case Report Of Ayurvedic Management of Shittapitta (Urticar-Ia). International Ayurvedic Medical Journal \{online\} 2021 \{cited October 2021$\} \quad$ Available from: http://www.iamj.in/posts/images/upload/2605_2608.pdf 